\title{
Modern Trends in Occupational Safety Management
}

\author{
Teresa Lis, Krzysztof Nowacki \\ Silesian University of Technology, Poland
}

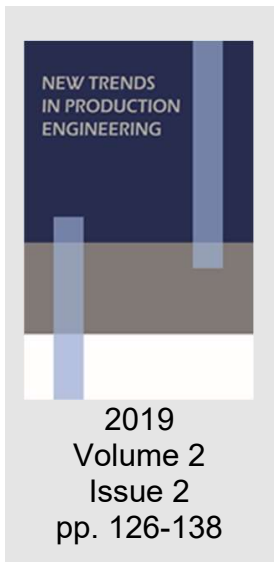

Date of submission to the Editor: 09/2019

Date of acceptance by the Editor: 11/2019

\section{INTRODUCTION}

For many years, legal regulations have had a decisive influence on the occupational health and safety in enterprises. They are usually limited to the definition of minimum requirements relating to the quality of the work environment.

The economic and political changes taking place in Poland as well as the social and economic transformations associated with them, as well as attempts to model the economic solutions of the highly industrialized countries, have caused an increase in interest in the issues of occupational safety (Roberts, 2015, Zhou et al., 2018, Auyong et al., 2016, Autenrieth et al., 2016, Rajaprasad \& Chalapathi, 2015, Gembalska-Kwiecien \& Skotnicka-Zasadzien, 2018). It results mainly from the conviction that in the present conditions proper management is the most effective means of ensuring the safety and health of the employee (Amyotte \& Lupien, 2017, Filimonov \& Gorina, 2019, Mohammadfam et al., 2017, Masso, 2015). Occupational safety management in an increasing number of enterprises is realised according to OHSAS 18001: 2007 or PN-N 18001:2004 standards. From 2021, ISO 45001:2018 will be the effective standard. This paper presents a new standard and compares the requirements in this standard with the requirements in the existing standards.

\section{OCCUPATIONAL SAFETY OVER THE CENTURIES}

Occupational safety and related to it accidents during performing work have accompanied humanity since time immemorial. Formerly, the strength of human muscles and/or animals was used for work, no advanced energy sources were used. This meant that the scale of threats to humans was lower than today, but it does not mean that there were no accidents at work. With each subsequent accident, the level of knowledge about threats to health and human life increased, which contributed to determining the basic principles of work safety. As early as in the $4^{\text {th }}$ century $\mathrm{BC}$, Hippocrates advised doctors in his writings: 
There are many professions related to the danger of diseases, so it is important that the doctor ask about the profession.

The Middle Ages brought about a rich flourishing of the craft, which was associated not only with an increase in accidents, but also with the enrichment of knowledge about the causes and ways to avoid mistakes. This made us aware of the need and purposefulness of codifying not only the secrets of production techniques, but also the principles of safe work. The legal acts issued by the rulers served this purpose as well. For example, the first so-called Mining ordinance, establishing the principles of searching and safe extraction of various minerals, including salt, was issued by the prince Leszek Biały in 1221 (Jaroszewski \& Horwath, 1993).

The development of manufactories and the beginnings of capitalism have sharpened the problem of accidents at work and the health of workers. The most valuable in this respect was the scientific and journalistic activity of Bernardino Ramazzini, who in the book entitled "Uczona rozprawa o chorobach rzemieślników" (Scholarly dissertation about craftsmen's diseases), issued in 1700 , described 52 professions and divided them into nine groups, from the most dangerous (miners, metallurgists) to the least dangerous ones (farmers). The transformation of manufactories into factories, the original capitalism of the nineteenth century and the birth of the working class have brought major changes in the field of occupational safety. Workplaces and equipment began to be introduced into the workplace, which on the one hand improved work and on the other hand created more and more dangerous situations. Security was started to be considered holistically and institutionally. Initially, only women and children in the workplace were protected. Then, the first factory inspections were created, which were responsible for the safety of the workplace. After a short time, the first security supervision was established.

In 1840, a factory inspection was established in France. Thirteen years later, the same organization was established by the Prussians, and in 1833 by the British, who were the pioneers of the nineteenth-century industry. In 1867, a private employers' association was established in France, and in 1906, the OSH services in metallurgical plants were established in the USA. The International Labour Organization was founded in the United States in 1919.

In Poland before 1914, the supervision over compliance with labour law was carried out by factory inspection (in the Russian Partition) and industrial inspection (in other partitions). The beginnings of Polish labour inspection bodies were created in 1915 under German occupation, and the labour inspection itself was established in 1919. The most important provisions regarding occupational safety in the Second Republic of Poland were codified in 1927-28 (Nowacki \& Lis, 2018)

\section{OCCUPATIONAL SAFETY IN POLISH AND INTERNATIONAL LEGISLATION}

Safety and protection of workers' health in the work environment have been the subject of Polish legal regulations for many years. The first normative acts in this 
field were ordinances of the President of the Polish Republic from 22 August 1927 on the prevention and combating of occupational diseases (Regulation of the President of Poland, 1927) and the Ordinance from 16 March 1928 on occupational health and safety (Regulation of the President of Poland, 1928). These regulations were fundamentally changed by the introduction of the Occupational Safety and Health Act on 30 March 1965 (Act, 1965). However, the most significant changes were made in 1974 by the announcement of the Act of 26.06.1974 - Labour Code (effective from January 1, 1975, Act, 1974), and then in 1996 an amendment to Section 10 of the Labour Code regarding health and safety at work. The international regulations in the field of occupational health and safety had a significant impact on the amendment of Section 10 of the Labour Code. The most important of them are the following:

- Convention No. 155 of the International Labor Organization on safety, workers' health and the working environment (www.mop.pl),

- Council directive from 12 June 1989 on the introduction of means to increase safety and improve workers' health at work, No 89/391/EEC, the so-called "Framework Directive" (www.osha.europa.eu).

Despite the non-ratification by Poland of all conventions, national labour legislation takes into account the provisions of these conventions and the implementing provisions are consistent, in whole or in large part, with the provisions of unratified conventions. In Community law, the EEC Directive is equivalent to the ILO convention. Both of these documents concern not so much the technique as the policy of protecting the health and life of an employee during work.

The ILO convention and the EEC directive, although they regulate issues in the same field, differ from each other. These differences result primarily from the nature of international organizations that these laws enacted. The International Labour Organization, as a body of the United Nations, unites as members many countries around the world, including poor countries, hence the requirements of the Convention are of general nature. They include, apart from the obligations of employers and employees in shaping safe working conditions, also obligations imposed on a country. The set level of requirements in the field of occupational safety and health protection, to which member countries should strive, is adapted to the level possible to be implemented by third world countries. The Directive, on the other hand, does not contain a list of tasks that the state should implement to ensure health and safety at work, obliging only member countries to take all necessary measures to ensure the application of the provisions contained in the directive. However, it regulates the tasks of the parties involved in creating safe and hygienic working conditions at a workplace. The European Framework Directive on Safety and Health at Work (Directive $89 / 391 /$ EEC) adopted on 12/06/1989 was a significant step in the effort to raise the level of safety and health in the workplace. It guarantees the introduction in the European Union of minimum health and safety requirements that member countries may maintain or for which they may introduce stricter measures. 
The provisions of Directive 89/391/EEC were taken into account primarily in the Act of 26 June 1974 - the labour Code, and especially in its 10 section, "Occupational health and safety" and in secondary legislation to this Act.

\section{OCCUPATIONAL SAFETY MANAGEMENT SYSTEMS}

Although issues related to occupational safety were solved by people over many centuries, it was only in the last years of the twentieth century that occupational safety has been approached in a systemic way.

Particular attention in the aspect of occupational safety management deserves the first national standard in the world referring to this management system. The former BS 8800 (Standard BS 8800, 1996) standard was published by the British BSI Standardisation Organisation in 1996. The purpose of the norm was to facilitate the creation and implementation of such an occupational safety management system that can be integrated with the general business management system. For this purpose, the norm provides two concepts for occupational safety management. The first concept is consistent with the traditional approach to the problems of occupational safety in Great Britain, while the second is consistent with the management concept defined in the ISO 14001 standard based on the continuous improvement cycle.

A year later, more standards were published - the Dutch NPR 5001 (Standard NPR 5001, 1997) standard and the standard AS/NZS 4804-1997 (Standard AS/NZS 4804, 1997) developed by the Australian-New Zealand Technical Committee. The concept of the safety and occupational protection management system was based on the approach set out in the ISO 14001 standard referring to environmental management.

In other highly developed countries, such as the United States, Scandinavian countries or Japan, the systemic approach to occupational safety and protection management functions not on the basis of standards, but the provisions of national law. Such health and safety management systems may be more effective because they are regulated by law and controlled by state institutions supervising working conditions.

In the United States there is also a so-called Voluntary Protection Programs VPP, supervised by Occupational Safety and Health Administration (OSHA). Within this system, the production plants implement systemic work safety management, following the OSHA guidelines (Standard VPP, 1996).

As more and more countries showed interest in the systematic management of occupational health and safety, the International Organization for Standardization ISO in 1996 attempted to develop standards that would be adopted internationally. The ongoing globalization forces the necessity to standardize many systems, including the approach to systemic management of occupational safety on an international scale. In 1999, 14 different certifying and standardization bodies and consulting companies formed a consortium led by BSI (British Standard Institution). The aim was to create international normative documents OHSAS (Occupational Health and Safety Assessment Scheme) containing requirements and guidelines for systemic management of 
occupational health and safety. As a result of these activities, the first document in this series was developed - OHSAS 18001:1999 (Standard OHSAS 18001, 1999).

In the EU, investors who commission construction, assembly, insulation, scaffolding, etc., require subcontractors to have a certified safety, health and environmental management system according to the Dutch SCC/VCA standard. The name VCA comes from the Dutch language - VGM Checklijst Aannemers (Checklist VGM for subcontractors). The acronym VGM:

- V (veiligheid) - safety,

- $\mathrm{G}$ (gezondheid) - health,

- M (milieu) - environment.

The standard was developed in the Netherlands in 1990 in the petrochemical industry. The authors were directed by the slogan: "Practical checklist, no nonsense at the workplace". In 1997, the English version of SCC (SHE Checklist Contractors) was developed. The acronym SHE (Safety, Health, Environment) has the same meaning as the Dutch VGM. The Dutch Accreditation Council approved a new version of SCC 2017/6.0, more than previous versions aimed at safety and improvement of safe behaviour in the workplace. One of the requirements of SCCNCA is that employees of construction, assembly, etc. enterprises have diplomas confirming the knowledge of health and safety and environmental protection appropriate for independent and safe performance of duties. In addition to diplomas for enterprises, SCC/VCA certificates are issued. Company's certification can take place at various levels, depending on the scope of work carried out by the subcontractor at the client's premises:

- $\mathrm{VCA}^{*}$ requirements for work places; mono-disciplinary, routine, not very complex work, without the participation of subcontractors.

- $\mathrm{VCA}^{* *}$ extended requirements for organizational and company management requirements; multidisciplinary work, not only routine, moderately complex, with or without subcontractors.

- VCAPetro requirements similar to $\mathrm{VCA}^{* *}$ - requirements for subcontractors working in the petrochemical industry, multidisciplinary, involving subcontractors or as the main contractor.

In Table 1 it was presented a synthetic comparison of the most important elements of OHSAS 18001, PN-N-18001, SCC/VCA.

For the beginning of activities in Poland in the field of promoting systemic health and safety management in enterprises, the meeting of the labour Protection Council at the parliament of the Republic of Poland can be considered in January 1998 and then appointment of the Standardisation Problem Commission No 276 for Occupational Health and Safety Management. The increasingly common management according to the ISO 9000 and 14000 standards and the development of the concept of integration of management systems have caused in many production plants attempts to cover the sphere of occupational safety and health with the principles of systemic management. 
Table 1 Comparison of the most important elements OHSAS 18001, PN-N 18001 and SCC/VCA

\begin{tabular}{|c|c|c|c|c|}
\hline On. & Application/requirements & OHSAS 18001 & PN-N 18001 & SCC/VCA \\
\hline 1 & $\begin{array}{l}\text { Does the system include process management } \\
\text { in the area of health and safety? }\end{array}$ & YES & $\mathrm{NO}$ & YES \\
\hline 2 & $\begin{array}{l}\text { Are the environmental protection tasks } \\
\text { included in the system? }\end{array}$ & NO & NO & YES \\
\hline 3 & $\begin{array}{l}\text { Is supervision of documentation and records } \\
\text { required in the system? }\end{array}$ & YES & YES & YES \\
\hline 4 & $\begin{array}{l}\text { Is there a requirement for corrective and } \\
\text { preventive actions in the organization? }\end{array}$ & YES & YES & YES \\
\hline 5 & $\begin{array}{l}\text { Is there a requirement for internal auditing } \\
\text { in the organization? }\end{array}$ & YES & YES & YES \\
\hline 6 & $\begin{array}{l}\text { Is there a requirement for management } \\
\text { reviews in the organization? }\end{array}$ & YES & YES & YES \\
\hline 7 & $\begin{array}{l}\text { Is there a requirement in the organization } \\
\text { to carry out continuous improvement? }\end{array}$ & YES & YES & NO \\
\hline 8 & $\begin{array}{l}\text { Is there a requirement in the organization to } \\
\text { identify and manage health and safety risks? }\end{array}$ & YES & YES & YES \\
\hline 9 & $\begin{array}{l}\text { Is there a requirement to prepare the } \\
\text { organization for major accidents? }\end{array}$ & YES & YES & YES \\
\hline 10 & $\begin{array}{l}\text { Should accident and potentially accident } \\
\text { situations be investigated in the organization? }\end{array}$ & YES & YES & YES \\
\hline 11 & $\begin{array}{l}\text { Does the organization need to set health and } \\
\text { safety goals and monitor their performance? }\end{array}$ & YES & YES & YES \\
\hline 12 & $\begin{array}{l}\text { Does the organization have to have } \\
\text { a specialist for health and safety } \\
\text { and environmental protection? }\end{array}$ & YES/NO & YES/NO & YES \\
\hline 13 & $\begin{array}{l}\text { Should the organization identify training needs } \\
\text { and set up a training plan? }\end{array}$ & YES & YES & YES \\
\hline 14 & $\begin{array}{l}\text { Do you have to consult your employees about } \\
\text { health and safety? }\end{array}$ & YES & YES & YES \\
\hline 15 & $\begin{array}{l}\text { Is the system subject to accredited } \\
\text { certification? }\end{array}$ & $\begin{array}{l}\text { YES } \\
\text { any certifica- } \\
\text { tion body }\end{array}$ & $\begin{array}{l}\text { YES } \\
\text { PCA }\end{array}$ & $\begin{array}{l}\text { YES } \\
\text { DNV }\end{array}$ \\
\hline 16 & $\begin{array}{l}\text { In what part of the world is the certificate } \\
\text { recognized? }\end{array}$ & Globally & Poland & Europe \\
\hline 17 & $\begin{array}{l}\text { Do you have to meet other requirements } \\
\text { to have a certificate? }\end{array}$ & $\begin{array}{c}\text { YES } \\
\text { local legal } \\
\text { requirements }\end{array}$ & $\begin{array}{l}\text { YES } \\
\text { Polish legal } \\
\text { requirements }\end{array}$ & $\begin{array}{c}\text { YES } \\
\text { employees } \\
\text { with } \\
\text { certificates } \\
\text { SCC/VCA }\end{array}$ \\
\hline
\end{tabular}

Source: own elaboration based on OHSAS 18001, PN-N 18001, SCC/VCa

As a result of reconciliation and preparatory work, on February 26, 1998, the Standardization Problem Committee (NKP) No. 276 for Occupational Safety and Health Management was established. The Commission included representatives of industrial enterprises, state institutions, research and development units and employees.

As a result of the activity of NKP No. 276 on July 15, 1999, the first Polish standard PN-N-18001 (Standard PN-N-18001, 2004), defining the specifications for the occupational safety and health management system, was established. The second standard developed by NKP: PN-N-18002 (Standard PN-N-18002, 2011) contains general guidelines for occupational risk assessment, and the next from the series PN-N-18004 (Standard PN-N-18004, 2001) standard contains guidelines for practical implementation in enterprises of systemic management of occupational health and safety. These standards have the status of non-compulsory standards and constitute national rules for the creation of a health and safety management system and for conducting work related to the assessment of occupational risk. These standards in their content have 
transferred the provisions of EU standards, which correspond to the rules in force in the European Union countries regarding the assessment of occupational risks and documenting both the assessments carried out and functioning of the system.

\section{A NEW STANDARD OF OCCUPATIONAL SAFETY MANAGEMENT (ISO 45001:2018)}

By the decision of the International Organization for Standardization (ISO) March 12, 2018. The ISO 45001:2018 (Standard 45001, 2018) standard has been published, which will replace current health and safety standards, such as OHSAS 18001:2007 or PN-N 18001:2004. The new standard has the status of the Polish Standard PN-ISO 45001:2018-06. Occupational health and safety management systems - Requirements with guidance use. This standard was approved by the President of PKN on 19.06.2018. The national committee responsible for the standard is KT No. 276 for Occupational Safety and Health Management. The standard replaces PN-N-18001:2004; PN-N-18004:2001 and PN-N-18011:2006.

The ISO 45001:2018 standard is based on the directives of the International Labor Organization. Its implementation is a strategic and operational decision for the organization. The new standard enables the development of a comprehensive health and safety policy leading to a safe work environment, the elimination of nuisance factors and those that can cause accidents and absenteeism caused by work-related problems. The ISO 45001:2018 standard applies the concept of a high-level structure. This comprehensive approach enabled full integration with other management systems, such as ISO 9001:2015 and ISO 14001:2015. The new ISO 45001 standard and in particular the mechanisms used in it give assurance to organizations that their Management Systems are compliant with applicable law, monitor any threats that may affect the organization's activities and potentially protect employees' lives, reduce the number of accidents, related costs and they increase employees morale. ISO 45001:2018 applies to any organization regardless of its size, type and activity. The $\mathrm{OH} \& \mathrm{~S}$ management system approach applied in this document is founded on the concept of Plan-Do-Check-Act (PDCA), as shown in Fig. 1.

Organizations with the OHSAS 18001, PN-N-18001 certificate have a 3-year transition period for migration to the new ISO 45001 standard. The deadline is March 11, 2021. Until that date, the entire certification process must be completed, including an explanation of possible nonconformities.

The ISO 45001 standard has a slightly different structure from the norm OHSAS18001 and PN-N-18001.

Table 2 presents a comparison of the most important elements of the PN-ISO 45001:2018 and PN-N-18001:2004 standards. 


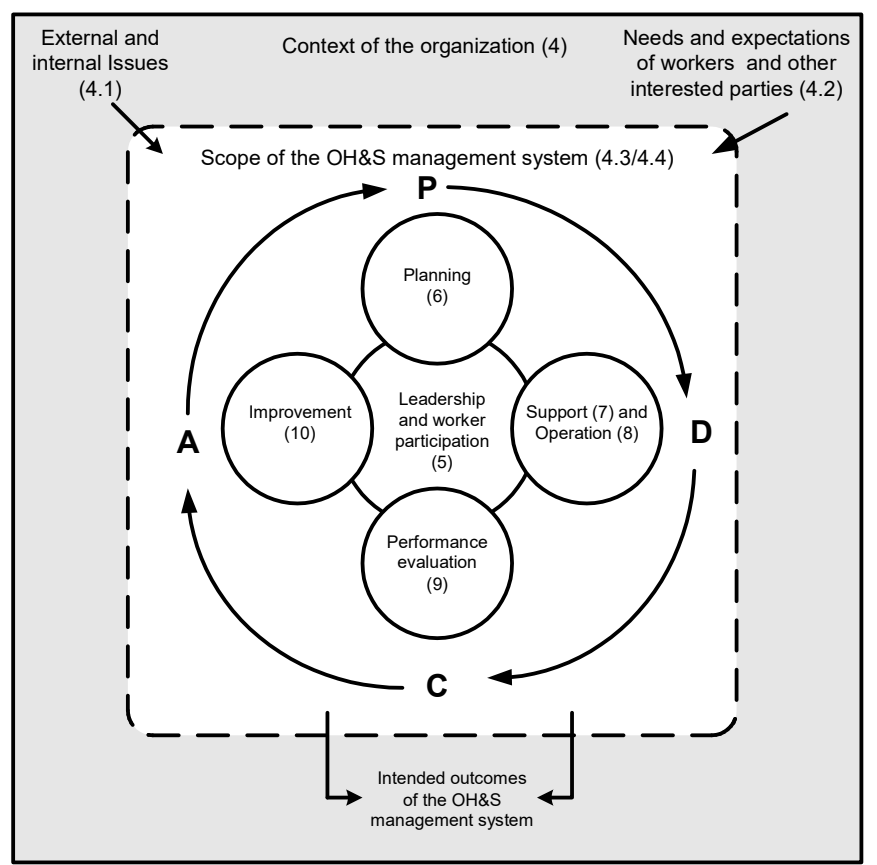

Fig. 1 Relationship between PDCA and the framework in standard ISO 45001

Table 2 Comparison of the most important elements OHSAS 18001, PN-N-18001 and SCC/VCA

\begin{tabular}{|c|c|}
\hline ISO 45001:2018 & PN-N-18001:2004 \\
\hline Foreword & Foreword \\
\hline $\begin{array}{l}\text { Introduction } \\
0.1 \text { Background } \\
0.2 \text { Aim of an } \mathrm{OH} \& \mathrm{~S} \text { management system } \\
0.3 \text { Success factors } \\
0.4 \text { Plan-Do-Check_act cycle } \\
0.5 \text { Contens of this document }\end{array}$ & $\begin{array}{l}\text { Introduction } \\
\text { A general description of the occupational } \\
\text { safety and health management system model } \\
\text { adopted in this standard }\end{array}$ \\
\hline 1. Scope & 1. Scope of standard \\
\hline 2. Normative references & 2. Normative references \\
\hline 3. Terms and definitions & 3. Definitions \\
\hline $\begin{array}{l}\text { 4. Context of the organization } \\
\text { 4.1. Understanding the organization and its context } \\
\text { 4.2. Understanding the needs and expectations of } \\
\text { workers and other interested parties } \\
\text { 4.3. Determining the scope of the OH \& S } \\
\text { management system (The organization shall } \\
\text { determine and boundaries and applicability of } \\
\text { the OH \& S management system to establish } \\
\text { its scope). } \\
\text { 4.4. OH \& S management system (The organization } \\
\text { shell establish, implement, maintain and } \\
\text { continually improve an OH \& S management } \\
\text { system, including the processes needed and } \\
\text { their interactions, in accordance with } \\
\text { the requirements of this document). }\end{array}$ & $\begin{array}{l}\text { 4.3.2. Legal requirements and other } \\
\text { requirements }\end{array}$ \\
\hline $\begin{array}{l}\text { 5. Leadership and worker participation } \\
\text { 5.1. Leadership and commitment } \\
\text { 5.2. OH \& S policy } \\
\text { 5.3. Organizational roles, responsibilities and } \\
\text { authorities } \\
\text { 5.4. Consultation and participation of workers }\end{array}$ & $\begin{array}{l}\text { 4.2. Commitment of top management and } \\
\text { occupational health and safety policy } \\
\text { 4.2.1. Commitment of top management } \\
\text { 4.2.2. Health and safety at work policy } \\
\text { 4.4.1. Structure, responsibility and entitlements } \\
\text { 4.2.3. Complicity of employees }\end{array}$ \\
\hline $\begin{array}{l}\text { 6. Planning } \\
\text { 6.1. Actions to address risks and opportunities. } \\
\text { 6.1.1. General (When planning for the } \mathrm{OH} \& \mathrm{~S} \\
\text { management system, the organization shall } \\
\text { consider the issues referred to context (4.1), } \\
\text { the requirements referred to interested parties } \\
\text { (4.2) and the scope of its } \mathrm{OH} \& \mathrm{~S} \text { management }\end{array}$ & $\begin{array}{l}\text { 4.3.Planning } \\
\text { 4.4.6. Safety risk management }\end{array}$ \\
\hline
\end{tabular}


system (4.3) and determine the risks and opportunities)

6.1.2. Hazard identification and assessment of risk and opportunities

6.1.3. Determination of legal requirements and other requirements

6.1.4. Planning action

6.2. $\mathrm{OH} \& \mathrm{~S}$ objectives and planning to achieve them

6.2.1. OH \& S objectives

6.2.2. Planning to achieve $\mathrm{OH} \& \mathrm{~S}$ system

7. Support

7.1. Resources

7.2. Competence

7.3. Awareness

7.4. Communication (Internal and External communication)

7.5. Documented information

8. Operation

8.1. Operational planning and control

8.1.1. General

8.1.2. Eliminating hazards and reducing $\mathrm{OH}$ \& $S$ risk

8.1.3. Menagament of change

8.1.4. Procurement (contractors and outsourcing)

8.2. Emergency preparedness and response

9. Performance evaluations

9.1. Monitoring, measurement, analysis and performance evaluation

9.2. Internal audit

9.3. Management review

10. Improvement

10.1. General

10.2. Incident, nonconformity and corrective action

10.3. Continual improvement

4.4.10. Subcontracting

4.3.2. Legal requirements and other

requirements

4.3.4.Planning action

4.3.3. General and specific goals

4.4.2. Providing resources

4.4.3. Training, awareness, competences and motivation

4.4.4. Communication

4.4.5.Documentation OH\&S system

4.4.7. Organizing activities and work related to significant hazards

4.4.9. Procurement

4.4.8. Prevention, preparedness and response to accidents at work and serious accidents

4.5. Checking and corrective and preventive actions

4.5.1.Monitoring

4.5.2. Examination of accidents at work, occupational diseases and potentially accidental events

4.5.3.Auditing

4.6. Management review

4.5.4. Nonconformity and corrective and preventive action

4.7. Continual improvement

Source: own elaboration based on Standard PN-ISO 45001 and PN-N 18001

As can be seen from the above statement, the new ISO 45001 standard differs from the current PN-N-18001 standard and covers a number of new activities that may have an impact on occupational safety. The main differences between the current PN-N-18001 standard and the new international standard ISO 45001 are presented below:

1. Unification of the structure:

- the unified structure of the standard takes into account a common layout with respect to systems based on ISO 9001, ISO 14001 standards and other management system standards;

- consideration of compatibility with other standards regarding different management systems is aimed at avoiding potential errors during integration of management systems, e.g. ISO 9001, ISO 14001.

2. Organizational context - Organization's environment: 
- a new element is the requirement for the organization to monitor internal and external factors that may have an impact on the organization's operations and its occupational safety;

- the organization's context within the meaning of the standard consists of factors that create the environment - the external and internal environment of the organization are distinguished. Internal and external factors include, for example, the emergence of new technologies in a given industry, applicable legal regulations, issues related to $\mathrm{HR}$ (e.g. availability of qualified employees) and sudden unfavourable weather conditions (e.g. flood);

- ISO 45001 standard requires the monitoring of these factors/threats by designated people.

3. Leadership

The new ISO 45001 standard places great emphasis on the role of management in the management system. Top management should demonstrate leadership and commitment to occupational safety management through:

- taking full responsibility for preventing accidents at work and work-related diseases and ensuring safety and health protection in the workplace;

- ensuring that the $\mathrm{OH} \& \mathrm{~S}$ policy has been established;

- ensuring integration of the health and safety management system requirements with the organization's business processes;

- providing resources necessary to establish, implement, maintain and improve the $\mathrm{OH} \& \mathrm{~S}$;

- ensuring active participation of employees or their representatives, using consultations at all management levels within the $\mathrm{OH} \& \mathrm{~S}$;

- managing and supporting people who have an impact on effectiveness of $\mathrm{OH}$ $\& S$.

4. Actions related to risks and opportunities

- when determining the risk and chances of the $\mathrm{OH} \& \mathrm{~S}$ and its intended results, the organization should take into account hazards, risks related to health and safety and other types of risks, as well as opportunities to eliminate risks taking into account legal and other requirements.

5. Outsourcing:

- the organization should provide control over commissioned functions and processes.

- the organization should ensure compliance of its outsourcing arrangements

- with legal requirements and other requirements and compliance with the intended objectives of the $\mathrm{OH} \& \mathrm{~S}$.

6. Preventive actions:

- in ISO 45001, the deadline for preventive action has been removed. The whole norm is aimed at preventing incidents in the area of occupational safety.

\section{SUMMARY}

Occupational safety management has been recognized in a number of enterprises in Poland and around the world as one of the basic activities. 
Entrepreneurs learned that a higher level of occupational safety is not only a better image of the company, but also concrete financial profits. The need for systemic safety management generated various solutions: voluntary, standardized, legal. This diversity indicates a different approach to occupational safety in different countries. With globalization, there has been a growing tendency to unify labour safety requirements. The first international attempt was the OHSAS 18001 standard. Because this standard and standards compatible with it (e.g. PN-N-18001) did not ensure full compliance with the quality management standards (ISO 9000 series) and environmental standards (ISO 14000 series). International Organization for Standardization has developed a new ISO 45001 standard. This standard takes into account the guidelines of the International Labour Organization and ensures full integration with quality and environmental management systems. The new ISO 45001 standard with its structure differs from the previously applicable OHSAS 18001 and Polish PN-N18001. It seems that the biggest difference is the inclusion of the so-called Context of the Organization.

The organization shall determine external and internal issues that are relevant to its purpose and that affect its ability to achieve the intended outcome(s) of its $\mathrm{OH}$ \& $\mathrm{S}$ management system. An understanding of the context of an organization is used to establish, implement, maintain and continually improve its $\mathrm{OH} \& \mathrm{~S}$ management system. Internal and external issues can be positive or negative and include conditions, characteristics or changing circumstances that can affect the $\mathrm{OH} \& \mathrm{~S}$ management system, for example external issues, such as: the cultural, social, political, legal, financial, technological, economic and natural surroundings and market competition, whether international, national, regional or local and internal issues, such as: governance, organizational structure, information system, the culture in the organization, working conditions.

The publication by International Organization for Standardization a new standard ISO 45001:2018. "Occupational health and safety management systems - Requirements with guidance for use" it proves an increasingly serious approach to systemic management of $\mathrm{OH} \& \mathrm{~S}$ and on a global scale.

\section{REFERENCES}

Act from 30 march 1965 on occupational safety and health, Dz. U 1965, Nr 13, poz. 91. Act from 26 June 1974, Labor Code, Dz. U 1974, Nr 24, poz. 141.

Amyotte P. R., Lupien C. S. (2017) Methods in Chemical Process Safety, 1 pp. 87-148 Autenrieth D. A., Brazile W. J., Douphrate D. et al. (2016) Journal of Agromedicine, 21 (4) 364-372

Auyong H.-N., Zailani S, Surienty L. (2016) Work - A Journal of Prevention Assessment \& Rehabilitation, 53 (4) pp. 729-735

Filimonov V. A., Gorina L. N. (2019) Journal of Mining Institute, 235 pp. 113-122

Gembalska-Kwiecien A., Skotnicka-Zasadzien B. (2018) Proceedings of the $6^{\text {th }}$ International Conference Innovation Management, Entrepreneurship and Sustainability (IMES 2018), pp. 347-356

Jaroszewski P., Horwath L., (1993). Wieliczka salt mine. Publishing house Parol. 
Masso M. (2015) International Journal of Occupational Safety and Ergonomics, 21 (1) pp. $62-70$

Mohammadfam I., Kamalinia M., Momeni M. et al. (2017) Safety and Health at Work, 8 (2) $156-161$

Nowacki K., Lis T. (2018). Formation of a safe work environment p.1 [in]: Contemporary trends in production engineering. Publishing house Sophia.

Rajaprasad S., Chalapathi P. (2015) Safety and Health at Work, 6 (3) 200-2005

Regulation of the President of Poland from 22 August 1927 on the prevention of occupational diseases, DzU 1927, Nr 78, poz. 676.

Regulation of the President of Poland from 16 March 1928 on occupational safety and health, Dz. U 1928, Nr 35, poz. 325.

Roberts D. (2015) IEEE Industry Applications Magazine, 21 (3) pp. 67-74

Standard AS/NZS 4804-1997. Occupational health and safety management systems general guidelines on principles, systems and supporting techniques.

Standard BS 8800:1996. Guide to occupational health and safety management systems.

Standard ISO 45001:2018. Occupational health and safety management systems Requirements with guidance use.

Standard NPR 5001. Guide to occupational health and safety management systems. Technical Report. Nederlands Normalisatie-institut, September 1997.

Standard OHSAS 18001:1999 Occupational health and safety management systems. Specification. Occupational Health and Safety Assessment Series, BSI 1999.

Standard PN-N 18002:2011. Occupational safety and health management systems. General guidelines for risk assessment.

Standard PN-N 18004:2001. Occupational safety and health management systems. Implementation guidelines.

Standard 18001:2004. Occupational safety and health management systems. Requirements.

Standard VPP Revised Voluntary Protection Programs Policies and Procedures Manual: Instruction TED 8.1a. US Washington, D.C., Occupational Safety and Health Administration 1996.

www.mop.pl/doc/html/konwencje/k155.html (Accessed 22 February 2018).

www.osha.europa.eu/pl (Accessed 22 February 2018).

Zhou L., Cao Q., Yu K. et al. (2018) International Journal of Environmental Research and Public Health, 15 (5) Article Number: 868 


\begin{abstract}
.
Problems related to work safety have been accompanying humanity since the dawn of time. In times before the Industrial Revolution, human and animal muscle strength was used to work, and "safe work" solutions were developed and introduced individually by the user or supervising the work. Only a change in the way work was done due to the industrial revolution, the introduction of new energy sources, the transformation of manufactories into factories and the birth of the working class brought about greater, concrete changes. It was at that time that various machines and devices began to be introduced into the workplace, which on the one hand improved work and on the other hand created more and more potentially dangerous situations. Security was started holistically and institutionally. With the transformation and return of capitalism, the subject of real work safety returned. Health and safety was to be not only a fashionable slogan, but a value that was supposed to guarantee profit - in accordance with the principle that accidents reduce productivity. It was also connected with the process of adapting Polish law in the field of health and safety to the law of the European Union (EU), which resulted from Poland's pursuit of EU membership. Moreover, an important factor initiating these changes was the interest of enterprises in quality management systems compliant with the ISO 9000 series and environmental management systems compliant with the ISO 14000 series, and related attempts to adapt the system management concept to the area of occupational health and safety, resulting in PN-N standards 18000 series. This publication analyzes the new standard PN-ISO 45001:2018 - "Occupational health and safety management systems - Requirements with guidance for use" comparing it with the standard PN-N 18001:2004 - "Occupational health and safety management. Requirements".
\end{abstract}

Keywords: occupational safety, management systems, standard ISO45001, context of the organization 